\title{
Fruit Characteristics of Apple cv. Red Delicious as Influenced by Foliar Spray of Calcium Chloride and Boric Acid
}

\author{
N.A. Ganai ${ }^{1 *}$, Khalid Rasool ${ }^{1}$, G.H. Rather ${ }^{2}$, Zahoor Ahmed ${ }^{2}$ and Tahir Saleem ${ }^{2}$ \\ ${ }^{1}$ Division of Horticulture, FOA, Wadura SKUAST of Kashmir, India \\ ${ }^{2}$ Krishi Vigyan Kendra Kupwara, SKUAST of Kashmir, India \\ *Corresponding author
}

\begin{tabular}{|l|}
\hline Ke y w o r d s \\
Apple, Calcium, \\
$\begin{array}{l}\text { Boron, Quality } \\
\text { attributes }\end{array}$ \\
\hline Article Info \\
\hline $\begin{array}{l}\text { Accepted: } \\
\text { 07 February } 2018 \\
\text { Available Online: } \\
\text { 10 March } 2018\end{array}$ \\
\hline
\end{tabular}

\section{Introduction}

The modern apple is believed to have been
derived from South western Asia where the
The modern apple is believed to have been
derived from South western Asia where the

\section{A B S T R A C T}

The diverse agro climatic zones of the state offer the advantage of growing different fruits. However, Red Delicious gave impetus to commercial apple production in the valley. Apple tree like other plants needs different nutrients in varying quantities to achieve proper growth and fruiting. Besides major elements, macro and micro nutrients are also required in small quantities that assume critical importance when deficient as these are taken up by the plant and need to be replenished. In many cases the quality of harvest produce is determined by the content of the mineral nutrients. In addition, storing stability depends upon the content of distinct mineral nutrients such as calcium and boron. In the present study calcium and boron was applied as pre -harvest spray on Red Delicious apple at fortnightly interval in the month of July. Calcium chloride at $0.1 \%$, averaged over various concentrations of boric acid resulted in the maximum fruit length $(5.89 \mathrm{~cm})$ during both the years. Similarly, boric acid at the lowest concentration $0.05 \%$ indicated high fruit length to the tune of $5.94 \mathrm{~cm}$. The combined application of calcium chloride at $0.1 \%$ plus boric acid at $0.15 \%$ recorded the higher fruit diameter $(7.16 \mathrm{~cm})$ during first year while as control registered the lowest fruit diameter $(5.64 \mathrm{~cm})$. In the second year maximum fruit diameter $(7.14 \mathrm{~cm})$ was registered with $0.2 \%$ calcium chloride plus $0.15 \%$ boric acid. Kilany and Kilany (1991) also observed significant change in fruit size i.e., length and diameter with the application of calcium chloride and boric acid treatment on apple. The fruits treated with calcium chloride were firm and firmness increased progressively with an increase in calcium chloride concentration from 0.1 to 0.4 per cent. Boric acid at higher level registered maximum firmness in comparison to lower concentration as well as control. Calcium chloride at 0.4 per cent plus boric acid at 0.25 per cent attained maximum firmness when sprayed together. The combined application of calcium chloride and boric acid was found instrumental in increasing TSS as compared either of the nutrient spray application. Both the chemicals used as pre- harvest spray decreased acidity of fruits as compared to unsprayed fruit. Lowest acidity was observed with intermediate level of calcium chloride as well as boric acid during both the years. mix of native Malus species could have given fruits of good size and quality, attractive to man. The first attempt towards growing apple tree deliberately may have begun in the 
Middle- east or South Eastern Europe with the technique being spread by Greeks and Romans (Bultitude, 1983). Apple (Malus $\times$ domestica Borkh) is the most important temperate fruit of Jammu and Kashmir state. The earliest plantation must have been established in the Kashmir by the turn of sixteenth century. Emperor Jahangir, in his Tuzk praises the Kashmir apple as the 'apples of Kashmir are known for their goodness.' Among different cultivars existing in the state, Red Delicious is an important late season cultivar which accounts for lions share in apple production. Apple trees like other plants need different nutrients in varying quantities to achieve proper growth and fruiting. Nutrients are known to influence physiological process with in the plant system. The adequate nutrition is essential to maintain proper growth and achieve desirable level of good yield. Foliar application of nutrients is advantageous under the conditions of limited uptake by roots as influenced by adverse soil conditions, drought, submergence or extreme soil temperature. The calcium plays a key role in wide range of physiological process. The role of calcium is well known as a constituent of cell wall in the form of calcium pectate. Its role has been implicated in gaurd cell physiology and certain enzymes are activated by calcium (Marchesner, 1995). Boron is essential for carbohydrate metabolism and its deficiency causes cracking and internal and external cork development in the fruit. Keeping in view the role of nutrients on physiological attributes, the present investigation was undertaken on Red Delicious apple with the objective of studying the effect of calcium and boron on the quality of fruit.

\section{Materials and Methods}

The present studies on fruit characteristics of apple cv. Red Delicious as influenced by foliar spray of calcium chloride and boric acids were carried out at Experimental Farm, Division of
Pomology, SKUAST -K Shalimar during the cropping season of 2003-04 and 200405.Forty eight healthy trees of cv. Red Delicious were selected on the basis of uniform vigour. The cultural practices including fertilizer application were furnished as per the package of practices. The preharvest spray of $\mathrm{CaCl}_{2}(0.0,0.1,0.2,0.4 \%)$ and $\mathrm{H}_{3} \mathrm{BO}_{3}(0.0,0.5,0.15,0.25 \%)$ were sprayed twice at fifteen days interval commenced from the first week of July. The trees were sprayed with foot sprayer moving first in clockwise direction and then in anticlockwise direction to a slight run-off stage. The experiment was laid out in $4 \times 4$ factorial Randomized Block Design taking one tree per treatment as an experimental unit and the treatments were replicated thrice. The fruit of each treatment were harvested at optimum maturity and were analyzed for different parameters. The fruit length and diameter was recorded with the help of Vernier's calliper. The fruit firmness was measured with the help of Effegi model penetrometer FT3-27 with $11 \mathrm{~mm}$ probe. The soluble solids content was determined with the help of Erina make Japan refractometer (0-32\% range). The total tritable acidity was determined by titrating the juice with $\mathrm{N} / 10 \mathrm{NaOH}$ using phenolphthalein as an indicator. The results were expressed as percentage of malic acid.

\section{Results and Discussion}

Main effect of calcium chloride and boric acid was significant in increasing the fruit length during both the years (Table 1). Calcium chloride at $0.1 \%$, averaged over various concentrations of boric acid resulted in the maximum fruit length $(5.89 \mathrm{~cm})$ during both the years. Similarly, boric acid at the lowest concentration $0.05 \%$ indicated high fruit length to the tune of $5.94 \mathrm{~cm}$. At higher concentration of both the chemicals, the fruit length declined. However, fruit length attained at higher concentration was significantly 
higher in comparison to control. Application of lowest calcium chloride concentration $(0.1 \%)$ to the apple trees resulted in the maximum fruit diameter of $6.69 \mathrm{~cm}$ (Table 2). Boric acid $0.05 \%$ averaged over various concentrations of calcium chloride exhibited maximum fruit diameter of $6.27 \mathrm{~cm}$ during 2003. Fruit diameter during following year showed similar trend in response to calcium chloride treatment. The combined application of calcium chloride at $0.1 \%$ plus boric acid at $0.15 \%$ recorded the higher fruit diameter $(7.16 \mathrm{~cm})$ during first year while as control registered the lowest fruit diameter $(5.64 \mathrm{~cm})$.

In the second year maximum fruit diameter $(7.14 \mathrm{~cm})$ was registered with $0.2 \%$ calcium chloride plus $0.15 \%$ boric acid. Kilany and Kilany (1991) also observed significant change in fruit size i.e., length and diameter with the application of calcium chloride and boric acid treatment on apple. Similar results have been reported by Mehta and Jindal (1984) in plum. Calcium is required for cell elongation and cell division (Burstrom, 1968). There is now evidence that auxin induced $\mathrm{H}^{+}$ secretion of meristematic cells is related to the presence of $\mathrm{Ca}^{+2}$ (Marine, 1983).

With an increase in the dosage of calcium chloride drastic increase in the fruit firmness was noticed and maximum firmness of 17.23 $\mathrm{lb}$ PSI was recorded under $0.4 \%$ calcium chloride. However, lowest firmness of 15.83 lb PSI was attained when no calcium chloride was applied during the first year. Similarly, during 2004 maximum firmness of $17.51 \mathrm{lb}$ Psi was found with $0.4 \%$ calcium chloride (Table 3). In the year 2003 boric acid at $0.25 \%$ registered maximum firmness of $17.01 \mathrm{lb}$ Psi followed by firmness of $16.92 \mathrm{lb}$ PSI with $0.15 \%$ boric acid. However, boric acid at 0.25 and 0.15 per cent were statistically at par with each other. In the year 2004 boric acid at higher concentration gave firmness of $17.5 \mathrm{lb}$ PSI followed by $19.69 \mathrm{lb}$ PSI with 0.15 per cent boric acid. The combined application of calcium chloride and boric acid both at higher levels recorder fruit firmness of $17.70 \mathrm{lb}$. PSI and $17.66 \mathrm{lb}$. PSI during first and second year respectively. These results were in conformity with those of Glenn and Pooviah (1990) and Siddiqui and Bangerth (1995) which reported an increase in firmness with the application of calcium chloride and boric acid in apple. The fruit firmness has direct relation with calcium pectate as calcium interact with pectic polymers of cell wall and act as cementing agent which gives strength to the cell wall (Dey and Brinson 1984). Faust and Shear (1968) reported that spray of boron improves the mobility of calcium in the apple tree. Boron affects calcium nutrition when applied through spray (Shear and Faust, 1971).

In general, apple fruits recorded an increase in total soluble solids (TSS) content with the treatment of nutrient application compared to unsprayed fruits (Table 4). The highest increase in TSS of 13.10 and 13.08 per cent was noticed with 0.2 per cent calcium chloride spray during first and second year of study respectively. Comparison of boric acid treatment revealed that TSS recorded a significant increase at an intermediate level in comparison to control during both the years. The highest TSS was attained with the combined application of calcium chloride at 0.2 per cent and boric acid at 0.15 per cent which recorded TSS of 14.10 per cent and 14.34 per cent during first and following year respectively. The minimum TSS observed was found to be 11.09 and 11.11 per cent under control during 2003 and 2004 respectively. Highest TSS induced by chemical treatments Viz., calcium chloride and boric acid might be due to lesser utilization of sugars in metabolic processes as a result of reduced respiration (Gupta et al., 1980). The reduced rate of respiration could also cause accumulation of organic acids which have oxidized at the slower rate. 
Table.1 Effect of calcium chloride and boric acid on fruit length $(\mathrm{cm})$ of apple $\mathrm{cv}$. red delicious

\begin{tabular}{|l|l|l|l|l|l|l|l|l|l|l|}
\hline $\begin{array}{l}\text { Calcium chloride } \\
\text { concentration (\%) }\end{array}$ & \multicolumn{4}{|c|}{ 2003 } & \multicolumn{4}{c|}{ 2004 } \\
& Boric acid concentration (\%) & & \multicolumn{3}{|c|}{ Boric acid concentration (\%) } \\
\hline & B0 & B1 & B2 & B3 & Mean & B0 & B1 & B2 & B3 & Mean \\
\hline C0 & 5.12 & 5.67 & 5.23 & 5.45 & $\mathbf{5 . 3 7}$ & 5.10 & 5.64 & 5.23 & 5.44 & $\mathbf{5 . 3 5}$ \\
\hline C1 & 5.60 & 6.16 & 6.22 & 5.58 & $\mathbf{5 . 8 9}$ & 5.62 & 6.13 & 6.21 & 5.60 & $\mathbf{5 . 8 9}$ \\
\hline C2 & 5.19 & 6.11 & 6.19 & 5.43 & $\mathbf{5 . 7 3}$ & 5.16 & 6.10 & 6.20 & 5.39 & $\mathbf{5 . 7 1}$ \\
\hline C3 & 5.23 & 5.85 & 5.96 & 5.14 & $\mathbf{5 . 5 4}$ & 5.22 & 5.87 & 5.93 & 5.15 & $\mathbf{5 . 5 4}$ \\
\hline Mean & $\mathbf{5 . 2 9}$ & $\mathbf{5 . 9 4}$ & $\mathbf{5 . 9 0}$ & $\mathbf{5 . 4 0}$ & & $\mathbf{5 . 2 7}$ & $\mathbf{5 . 9 4}$ & $\mathbf{5 . 8 9}$ & $\mathbf{5 . 3 9}$ & \\
\hline
\end{tabular}

$\mathrm{CD}:(\mathrm{p}=0.05)$ :

Calcium chloride (C): 0.05

Boric acid (B): 0.05

$\mathrm{C} \times$ B Interaction: 0.10

Table.2 Effect of calcium chloride and boric acid on fruit diameter $(\mathrm{cm})$ of apple $\mathrm{cv}$.

Red Delicious

\begin{tabular}{|c|c|c|c|c|c|c|c|c|c|c|}
\hline \multirow{3}{*}{$\begin{array}{l}\text { Calcium chloride } \\
\text { concentration }(\%)\end{array}$} & \multicolumn{5}{|c|}{2003} & \multicolumn{5}{|c|}{2004} \\
\hline & \multicolumn{4}{|c|}{ Boric acid concentration (\%) } & \multirow[b]{2}{*}{ Mean } & \multicolumn{4}{|c|}{ Boric acid concentration (\%) } & \multirow[b]{2}{*}{ Mean } \\
\hline & B0 & B1 & B2 & B3 & & B0 & B1 & B2 & B3 & \\
\hline $\mathrm{CO}$ & 5.64 & 6.42 & 5.90 & 6.17 & 6.03 & 5.60 & 6.38 & 5.86 & 6.13 & 5.99 \\
\hline$\overline{\mathrm{C1}}$ & 6.32 & 7.07 & 7.16 & 6.20 & 6.69 & 6.33 & 7.08 & 7.12 & 6.23 & 6.69 \\
\hline $\mathbf{C 2}$ & 5.74 & 6.88 & 7.07 & 6.10 & 6.45 & 5.69 & 6.91 & 7.14 & 6.11 & 6.46 \\
\hline C3 & 5.86 & 6.53 & 6.71 & 5.67 & 6.19 & 5.82 & 6.57 & 6.68 & 5.72 & 6.20 \\
\hline Mean & 5.89 & 6.72 & 6.71 & 6.03 & & 5.86 & 6.73 & 6.70 & 6.05 & \\
\hline $\begin{array}{l}\text { CD: }(\mathrm{p}=0.05): \\
\text { Calcium chloride }( \\
\text { Boric acid }(\mathrm{B}): 0.0 \\
\mathrm{C} \times \mathrm{B} \text { Interaction: }\end{array}$ & $\begin{array}{l}0.03 \\
07\end{array}$ & & & $\begin{array}{l}0.03 \\
0.03 \\
0.07\end{array}$ & & & & & & \\
\hline
\end{tabular}

Table.3 Effect of calcium chloride and boric acid on fruit firmness (lb.psi) of apple cv. red delicious

\begin{tabular}{|c|c|c|c|c|c|c|c|c|c|c|}
\hline \multirow{3}{*}{$\begin{array}{l}\text { Calcium chloride } \\
\text { concentration }(\%)\end{array}$} & \multicolumn{5}{|c|}{2003} & \multicolumn{5}{|c|}{2004} \\
\hline & \multicolumn{4}{|c|}{ Boric acid concentration (\%) } & \multirow[b]{2}{*}{ Mean } & \multicolumn{4}{|c|}{ Boric acid concentration $(\%)$} & \multirow[b]{2}{*}{ Mean } \\
\hline & B0 & B1 & B2 & B3 & & B0 & B1 & B2 & B3 & \\
\hline $\mathrm{CO}$ & 15.36 & 15.73 & 16.10 & 16.12 & 15.83 & 15.36 & 15.63 & 15.88 & 16.94 & 15.95 \\
\hline C1 & 16.19 & 16.44 & 17.27 & 16.76 & 16.66 & 16.46 & 16.56 & 16.53 & 17.12 & 16.67 \\
\hline $\mathrm{C} 2$ & 17.01 & 17.11 & 17.11 & 17.48 & 17.18 & 16.67 & 16.80 & 17.17 & 17.21 & 16.96 \\
\hline C3 & 17.19 & 16.84 & 17.18 & 17.70 & 17.23 & 17.21 & 17.37 & 17.81 & 17.66 & 17.51 \\
\hline Mean & 16.44 & 16.53 & 16.92 & 17.01 & & 16.42 & 16.59 & 16.85 & 17.23 & \\
\hline
\end{tabular}

CD: $(\mathrm{p}=0.05)$ :

Calcium chloride (C): $0.23 \quad 0.06$

Boric acid (B): 0.23

$\mathrm{C} \times \mathrm{B}$ Interaction: 0.47
0.06

0.12 
Table.4 Effect of calcium chloride and boric acid on total soluble solids (\%) of apple cv. Red Delicious

\begin{tabular}{|c|c|c|c|c|c|c|c|c|c|c|}
\hline \multirow{3}{*}{$\begin{array}{l}\text { Calcium } \\
\text { chloride } \\
\text { concentration } \\
(\%)\end{array}$} & \multicolumn{5}{|c|}{2003} & \multicolumn{5}{|c|}{2004} \\
\hline & \multicolumn{4}{|c|}{$\begin{array}{l}\text { Boric acid concentration } \\
(\%)\end{array}$} & \multirow[t]{2}{*}{ Mean } & \multicolumn{4}{|c|}{ Boric acid concentration (\%) } & \multirow[t]{2}{*}{ Mean } \\
\hline & B0 & B1 & B2 & B3 & & B0 & B1 & B2 & B3 & \\
\hline $\mathrm{CO}$ & 11.09 & 11.21 & 13.72 & 11.53 & 11.89 & 11.11 & 11.17 & 13.69 & 11.56 & 11.88 \\
\hline $\mathrm{C1}$ & 11.19 & 11.98 & 13.85 & 13.03 & 12.51 & 11.15 & 12.07 & 14.15 & 12.90 & 12.57 \\
\hline $\mathrm{C2}$ & 12.86 & 12.36 & 14.10 & 13.10 & 13.10 & 12.60 & 12.35 & 14.34 & 13.05 & 13.08 \\
\hline $\mathrm{C3}$ & 11.45 & 12.03 & 14.06 & 13.15 & 12.67 & 11.18 & 12.25 & 14.28 & 13.10 & 12.70 \\
\hline Mean & 11.64 & 11.89 & 13.93 & 12.70 & & 11.51 & 11.96 & 14.11 & 12.65 & \\
\hline $\begin{array}{l}\text { CD: }(\mathrm{p}=0.05): \\
\text { Calcium chloride }( \\
\text { Boric acid (B): } 0.1 \\
\mathrm{C} \times \text { B Interaction: }\end{array}$ & .21 & & & $\begin{array}{l}0.0 \\
0.0 \\
0.1\end{array}$ & & & & & & \\
\hline
\end{tabular}

Table.5 Effect of calcium chloride and boric acid on acidity (\%) of apple cv. Red Delicious

\begin{tabular}{|c|c|c|c|c|c|c|c|c|c|c|}
\hline \multirow{3}{*}{$\begin{array}{l}\text { Calcium } \\
\text { chloride } \\
\text { concentration } \\
(\%)\end{array}$} & \multicolumn{5}{|c|}{2003} & \multicolumn{5}{|c|}{2004} \\
\hline & \multicolumn{4}{|c|}{$\begin{array}{c}\text { Boric acid concentration } \\
(\%)\end{array}$} & \multirow[t]{2}{*}{ Mean } & \multicolumn{4}{|c|}{ Boric acid concentration (\%) } & \multirow[t]{2}{*}{ Mean } \\
\hline & B0 & B1 & B2 & B3 & & B0 & B1 & B2 & B3 & \\
\hline $\mathrm{CO}$ & 0.256 & 0.245 & 0.236 & 0.227 & 0.241 & 0.256 & 0.236 & 0.227 & 0.218 & 0.234 \\
\hline $\mathrm{C1}$ & 0.254 & 0.222 & 0.193 & 0.212 & 0.220 & 0.245 & 0.216 & 0.200 & 0.202 & 0.216 \\
\hline $\mathrm{C2}$ & 0.214 & 0.214 & 0.185 & 0.207 & 0.205 & 0.207 & 0.214 & 0.191 & 0.202 & 0.203 \\
\hline C3 & 0.240 & 0.216 & 0.185 & 0.198 & 0.210 & 0.234 & 0.216 & 0.191 & 0.198 & 0.210 \\
\hline Mean & 0.241 & 0.224 & 0.199 & 0.211 & & 0.235 & 0.220 & 0.202 & 0.205 & \\
\hline $\begin{array}{l}\text { CD: }(p=0.05): \\
\text { Calcium chloride } \\
\text { Boric acid }(B): 0.0 \\
C \times \text { B Interaction: }\end{array}$ & $\begin{array}{l}\text { C): } 0.013 \\
3 \\
\text { N.S. }\end{array}$ & & & $\begin{array}{l}0.0 \\
0.0 \\
\mathrm{~N} .\end{array}$ & & & & & & \\
\hline
\end{tabular}

Increase in TSS content with the calcium chloride has also been reported by Raese and Drake (1993) in apple and pear fruits and Robson et al., (1989) in peach. Similarly, Randhawa et al., (1980) and Banday (1996) recorded higher TSS in Le Conte pears with 6 and 8 percent calcium chloride respectively.

A close examination of Table 5 indicated that calcium chloride at lowest level registered acidity of 0.220 per cent which decreased to 0.207 per cent when calcium chloride level was elevated to 0.2 per cent. With the further increase in calcium chloride concentration to 0.4 per cent, the acidity decreased. The data indicated the acidity of apple fruit showed a decrease with an increase in calcium chloride concentration during the following year. Acidity decreased from 0.224 to 0.199 per cent when concentration of boric acid was raised from 0.1 to 0.2 per cent. The interaction effect of calcium chloride and boric acid was found to be non-significant. However, the lowest acidity was observed with the combined application of calcium chloride at 0.2 per cent and boric acid at 0.15 
per cent while as the highest acidity was found when none of chemicals was sprayed.

Apple cv. Red Delicious was sprayed fortnightly with calcium chloride and boric acids at pre- harvest stage commenced from first week of July. The fruit was harvested at full maturity and analyzed for fruit length, firmness, TSS and acidity. Calcium chloride at lowest concentration drastically increased fruit size in comparison to other treatments including control. All the concentrations of boric acid increased fruit size in comparison to control and boric acid at 0.05 per cent was found most superior in increasing fruit size. The interaction effect of calcium chloride and boric acid recorded highest fruit length and diameter during both the years of the study. The fruits treated with calcium chloride were firm and firmness increased progressively with an increase in calcium chloride concentration from 0.1 to 0.4 per cent. Boric acid at higher level registered maximum firmness in comparison to lower concentration as well as control. Calcium chloride at 0.4 per cent plus boric acid at 0.25 per cent attained maximum firmness when sprayed together. Maximum TSS was noticed with 0.2 per cent calcium chloride while as boric acid at 0.15 per cent recorded maximum TSS than lower and higher levels. The combined application of calcium chloride and boric acid was found instrumental in increasing TSS as compared either of the nutrient spray application. Both the chemicals used as pre- harvest spray decreased acidity of fruits as compared to unsprayed fruit. Lowest acidity was observed with intermediate level of calcium chloride as well as boric acid during both the years.

\section{References}

Banday, F.A. (1996). Cold storage studies in pear cv. Le Conte. Ph D. Dissertation, P.A.U. Ludhiana, India.
Bultitude, J. (1983). Apples: A guide to the identification of international varieties. MacMillan Press London.

Burstrom, H.G. (1968). Calcium and plant growth. Biological Review, 43:287-316.

Dey, P.M. and Brinson, K. (1984). Plant cell wall. Adv. Carbohydrate Chem.Biochem.Pp.215-281.

Faust, M. and Shear, C.B. (1968). Corking disorders of apple- A physiological and biochemical review. Botanical Review. 34: 441-469.

Glenn, G.M and Pooviah, B.W. (1990).Calcium mediated post harvest changes in texture and cell wall structure and composition in Golden Delicious apple. Journal of American Society for Horticultural Sciences 115: 962-968.

Gupta, O. P. Jindal, P.C. and Singh, B.P. (1980). Effect of pre- harvest spray of calcium nitrate on the storage behavior of grape cv. Perlett. Haryana Agriculture University Journal Research 10:204-206.

Kilany, A.E. and Kilany, O.A. (1991). Effect of potassium and boron nutrients on growth, yield and fruit quality of Anna apple trees. Bulletin of Faculty of Agriculture University Cairo: 42(2):415-428.

Marme, D. (1983). Calcium transport and function. In: Inorganic plant nutrition (A. Lauchli and R.L Bieleski, eds) Pp 599-625. Encycl. Plant Physiol. New Series Vol 15B, Springer Verlag Berlin, Heildelberg, New York.

Marschner, H.1995. Mineral nutrition of higher plants. Second edition: Academic Press, Halcout Brace and Company Publishers London. Pp 285 \& 380.

Mehta, K. and Jindal, K.K. (1986). Effect of some nutrient sprays on fruit maturity and quality of Japanese plum (Prunus saliciana Lindl.) cv. Santa Rosa In: 
Advances in Research in Temperate Fruits. Proceedings of National Symposium on Temperate Fruits. pp. 203-207.

Raese, J.T and Drake, S.R (1993). Effect of pre-harvest calcium sprays on apple and pear quality. Journal of Plant Nutrition 16:1807-09.

Robson M.G, Hopfinger, J.A. and Eck, P. (1989).Post harvest sensory evaluation of calcium treated peach fruit. Acta Horticulturae, 254:173-77.
Shear, C. B. and Faust, M. (1971).Value of various tissue analysis in determining the calcium status of apple trees and fruit. Plant Annal Fert. Probl. Res. Adv. Plant Nut. R.M. Samjah (ed.) 1: 75-98.

Siddiqui, S and Bangreth, F. (1995). Effect of pre- harvest application of calcium on flesh firmness and cell wall composition of apples, influence of fruit size. Journal of Horticultural Science, 70:263-269.

\section{How to cite this article:}

Ganai, N.A., Khalid Rasool, G.H. Rather, Zahoor Ahmed and Tahir Saleem. 2018. Fruit Characteristics of Apple cv. Red Delicious as Influenced by Foliar Spray of Calcium Chloride and Boric Acid. Int.J.Curr.Microbiol.App.Sci. 7(03): 546-552.

doi: https://doi.org/10.20546/ijcmas.2018.703.065 